\title{
DWIE PODRÓŻE PO KAPITALIZMIE, CZYLI ODPOWIEDŹ JANOWI SOWIE
}

\author{
KACPER POBŁOCKI
}

\begin{abstract}
Abstrakt: Niniejszy artykuł stanowi odpowiedź na tekst „Kapitalizm. Historia krótkiego trwania - dziewiętnaście Long Reads o »tysiącu lat niewolnictwa«” autorstwa Jana Sowy. Ustosunkowuję się w nim do argumentów i zarzutów sformułowanych przez Sowę, a także przedstawiam własną opinię na temat roli społecznej publikacji naukowych oraz ich funkcjonowania w dyskursie akademickim. Główne kwestie poruszane w tekście to mój stosunek do teorii Karla Polanyi'ego (w szczególności do jego teorii trzech towarów fikcyjnych stanowiących podstawę kapitalizmu), wykładnia teoretycznego znaczenia sporu o pojęcie przestrzeni w analizie kapitalizmu oraz zagadnienie de-okcydentalizacji teorii.
\end{abstract}

Słowa kluczowe: historia kapitalizmu, Sowa, okcydentalizm, Polanyi, teoria zależności, teoria historii, krytyczna geografia 
Celem Kapitalizmu. Historii krótkiego trwania miało być zwrócenie uwagi na pewien zaskakujący fakt. Mimo że przez ostatnie 25 lat słowo „kapitalizm” nie schodzi z ust polityków, publicystek czy ekspertów, mimo że teoretycznie to właśnie w projekt budowania kapitalizmu zaangażowane jest od dekad całe polskie społeczeństwo, to w sumie nie wiadomo, czym ten kapitalizm właściwie jest. A obiegowe definicje (wolny rynek, wolna konkurencja etc.) sa albo mało precyzyjne, albo (a często także) zupełnie oderwane od rzeczywistości - czy to tej polskiej, czy globalnej. O ile na świecie trwa (w zasadzie od stu lat) nieprzerwana debata o tym, czym jest i skąd wziął się kapitalizm, o tyle w Polsce - mimo że to właśnie nasz kraj miał być podręcznikowym przykładem budowania kapitalizmu (rzekomo) od zera - zupełnie o tym cicho. W zasadzie ostatnią książką napisaną przez rodzimego autora, dotykająca kwestii istoty i genezy kapitalizmu, jest (skądinąd rewelacyjna) pozycja Jerzego Topolskiego pt. Narodziny kapitalizmu w Europie, opublikowana po raz pierwszy w 1965 roku. Moim celem było zatem ocucenie tego słonia, który drzemie bezgłośnie w kącie debaty - zarówno publicznej, jak i naukowej.

Fakt, że w ciagu pół roku ukazało się dwanaście recenzji tej książki (pełna lista znajduje jest na końcu tego tekstu), świadczy o tym, iż spotkała się ona z zainteresowaniem. Cel mój zatem został, przynajmniej w pewnym stopniu, osiągnięty. Jako że niedawno odbyła się ostatnia planowana przez nas debata wokół Kapitalizmu, myślę, że nadszedł dobry moment, aby dokonać swoistego podsumowania tych reakcji, dyskusji oraz rozmów, a także przedstawić moje własne stanowisko w kwestii kilku kontrowersji, które pojawiły się w związku z publikacja. Odpowiedzi domaga się przede wszystkim najbardziej drobiazgowa i najobszerniejsza (70 tys. znaków!) recenzja napisana przez Jana Sowę. Z jednej strony, dziękuję Jankowi za poświęcenie Kapitalizmowi tak dużej uwagi oraz cieszę się, że - jako czytelnik - miał z tej lektury frajdę. Z drugiej strony, nie dziwi mnie zupełnie fakt, iż Sowa jako autor - ma z Kapitaliz̧mem problem. Myślę, że problem, jaki Sowa ma z takim myśleniem i pisaniem o kapitalizmie, takim stosunkiem wobec tradycji polskiej szkoły historii gospodarczej i wreszcie z takim uprawianiem nauki, jakie stoi u podstaw Kapitalizmu, ilustruje bardziej fundamentalną różnicę między nami - to różnica zdań na temat tego, na czym polega rola publicznego intelektualisty oraz czym jest praktyka teoretyczna. Wyartykułowaniu tych kwestii chciałbym poświęcić niniejszy tekst.

\section{Praca teoretyczna}

Najważniejszą częścia Kapitaliæmu z mojej perspektywy jest część najkrótsza, czyli podziękowania. To w niej kryja się odpowiedzi na wiele z pytań, które stawia Sowa. Jako że część czytelniczek, zarówno recenzji, jak i niniejszego tekstu, być może nie miała książki w ręki, pozwolę sobie ją przytoczyć: 
Pisanie podziękowań w publikacjach akademickich rządzi się zaskakująco sztywnymi regułami. Zasada jest prosta: najpierw należy skrupulatnie wymienić osoby, które przyczyniły się do powstania książki, a następnie oświadczyć, że wszelka odpowiedzialność za zawarte w niej treści spoczywa tylko i wyłącznie na barkach autora bądź autorki. Nie jestem w stanie złożyć takiej deklaracji. Jeśli okazie się że nie mam racji, to razem ze mną mylić się będzie cała armia ludzi, na badaniach czy przemyśleniach których oparty jest mój wywód. Jeśli mamy poważnie traktować idee uprawiania nauki jako trudnego balansowania na ramionach swoich poprzedników (oraz koleżanek i kolegów), to tego rodzaju gesty stanowia zbędna kokieteriec Nauka wydaje mi się jedną z nielicznych dziedzin, w których można - a nawet należy - mówić o zbiorowej odpowiedzialności (Pobłocki 2017, 551).

Nie jest to wymigiwanie się od odpowiedzialności, ale gest, którego celem jest zarysowanie mojego stanowiska wobec pracy intelektualnej. Dlatego w tym świetle mało zrozumiały jest dla mnie zarzut Sowy, że Kapitalizm pretenduje do oryginalności, ale po bliższej inspekcji oryginalny okazuje się nie być. Sowa twierdzi, że nie dotrzymuję obietnicy składanej czytelniczkom, a podstawową słabością Kapitalizmu jest „skłonnoś[ć] autora do przedstawiania własnej refleksji jako zasadniczego zwrotu - reorientacji, używając kategorii kluczowej dla Pobłockiego w rozumieniu kapitalizmu. Połączone jest to z przemilczaniem lub błędnym intepretowaniem dyskusji oraz prac zawierających wszystkie właściwie elementy układanki, którą bawi się autor". I dalej: „w zasadzie wszystkie elementy jego konstrukcji był już nie raz wykładane na stół, na którym toczy się intelektualna rozrywka zwana tworzeniem wiedzy o świecie" - przekonuje Sowa.

Jako dowód Sowa przytacza niektóre tezy, które stawiam w Kapitaliz̨mie, a następnie pisze, że idee te można zaleźć już u Marksa albo u takich autorów jak David Graeber, Robert Brenner czy Giovanni Arrighi. Demaskowanie mojego przypisywania sobie czyjegoś dorobku stanowi w zasadzie większą część recenzji Sowy. Autor zaczyna to od zdania: „Nie jest jednak prawda, że propozycja Połockiego, aby zrezygnować z tak silnego akcentowania pracy najemnej [w dyskusji o kapitalizmie], to zasadnicze novum", i przywołuje tutaj... Davida Graebera, który przede mna patrzył na kapitalizm przez pryzmat instytucji niewolnictwa. Na potwierdzenie tej tezy Sowa mógłby spokojnie zacytować któryś z fragmentów Kapitaliæumu, gdyż to (między innymi) na dorobku Graebera opieram swój argument. Piszę o tym wprost między innymi tutaj: „Zamiast zakładać, ze to praca najemna jest tym, co wyrózinia kapitalizm jako epoke, od innych, wcześniejszych okresów, możemy, idac tropem wyznaczonym przez Davida Graebera, uznać niewolnictwo za instytucję wyznaczajaca istote kapitalizmu jako ustroju” (Pobłocki 2017, 342, podkr. - KP). To samo dotyczy pozostałych autorów, których idee rzekomo przedstawiam jako swoje własne odkrycia. Wystarczy przejrzeć indeks Kapitaližmu, aby zobaczyć, jak ważnymi postaciami dla tej książki są Arrighi czy Brenner. 
Podobnie jest z zarzutem Sowy, że to Karl Polanyi, a nie Kacper Pobłocki, jako pierwszy rozumiał kapitalizm jako system oparty na rynku pracy, pieniądza oraz ziemi. „Tu właściwie mamy dokładne powtórzenie koncepcji Polanyi'ego z Wielkiej transformacji, czego zreszta Pobłocki nie kryje", pisze Sowa. Faktycznie, nie kryję tego. Co więcej, mówię wyraźnie we wstępie, że to właśnie Polanyi stanowi najważniejszą inspirację dla mojego projektu. Ale istnieja też istotne różnice między Wielka transformacja a Kapitaližmem. Nie wiem, dlaczego Sowa twierdzi, że moja książka jest „dokładnym powtórzeniem” teorii Polanyi’ego. Nie trzeba być bardzo uważnym czytelnikiem Kapitalizmu, ani nawet znawcą Wielkiej transformacji, aby zobaczyć, że tak nie jest. Zresztą Polanyi'emu też Sowa zarzuca wtórność:

\begin{abstract}
[n]awet sam Polanyi nie jest zatem całkiem oryginalny w swojej definicji dziewiętnastowiecznego kapitalizmu. Pomimo to Pobłocki obstaje przy twierdzeniu, że jego własne rozważania stanowią zasadniczą reorientację teoretyczno-pojęciową, co jest dziwne, bo przecież książka Polanyi'ego to klasyka - ukazała się w 1944 roku. To prawda, że jest niestety słabo obecna i zasługuje na znacznie większą uwagę. Bardzo dobrze się stało, że Pobłocki umieszcza tego właśnie autora w centrum swoich rozważań.
\end{abstract}

Tutaj właśnie ujawnia się przedziwny stosunek Sowy do Kapitalizmu - z jednej strony chyba dobrze, że Kapitaližm się ukazał, bo coś tam odświeża, ale też źle, bo wszystko to już kiedyś igdzieś było. Ale jeśli nawet Polanyi nie jest dla niego oryginalny, to kto jest? Oczywiście można zawsze powiedzieć, że Marks, bo u Marksa wszystko już było, ale jemu również można by zarzucić to samo. Przecież nawet Marks nie był Robinsonem Crusoe filozofii, a jego teoria wyrosła z szeregu tradycji intelektualnych.

Takie postawienie sprawy prowadzi do tego, że przeoczona zostaje rzecz najważniejsza. Kapitalizm nie jest referowaniem ani popularyzacja teorii Polanyi'ego, ale raczej próba przepisania tej książki pięćdziesiąt lat później. Przepisania rozumianego nie jako odtworzenie jej słowo w słowo (to faktycznie byłoby mało oryginalne), ale jako spojrzenie na współczesny świat społeczno-ekonomiczny przez jej pryzmat teoretyczny. Piszę o tym wyraźnie we wstępie i wyjaśniam też, dlaczego wykonuję taki zabieg. Cała struktura Kapitalizmu zbudowania jest wokół trzech kluczowych dla Polanyi'ego pojęć: pracy, ziemi oraz pieniądza. Oczywiście Polanyi nie był pierwszą osobą która użyła tych słów, ale był pierwszą osobą, która twierdziła, iż są to „towary fikcyjne” i stworzyła autorską narrację na temat tego, jak wyłonienie się rynków pracy, ziemi i pieniądza stanowiło narodziny brytyjskiego kapitalizmu. Każdy rozdział Kapitaliżmu poświęcony jest któremuś z tych trzech Polanyi'owskich filarów. Często też omawiam, na czym polega ich współzależność i jak przebiega interakcja między nimi. $\mathrm{Na}$ przykład po tym, jak w rozdziałach 2-6 analizuję to, czym jest i jak funkcjonuje we współczesnym kapitalizmie pieniądz, opisuję relacje między pieniądzem a przestrzenią 
(rozdziały 7-8) oraz pracą (rozdziały 9-10). Podobnie jest w drugiej części książki - choć tam zaczynam od analizy pracy (rozdziały 11-13), potem wracam do kwestii pieniądza (rozdział 14), a kończę analizą przestrzeni (15-17).

Co więcej, optyka Polanyi'ego nie tylko jest obecna w konstrukcji książki - w Kapitalizmie dokonuję również reinterpretacji tego, czym faktyczne są owe trzy fundamenty kapitalizmu. Sporo bowiem wydarzyło się w humanistyce od 1944 roku. Gdy Polanyi pisze o pracy jako o towarze fikcyjnym, to chodzi mu o rynek pracy najemnej. Gdy pisze o pieniądzu, to chodzi mu o brytyjski system oparty na standardzie złota. Gdy pisze o ziemi, chodzi mu o środowisko naturalne. Gdy ja piszę o pracy, to definiuję ją (właśnie za Graeberem czy też za Sidem Mintzem) w kontekście instytucji niewolnictwa. Gdy piszę o pieniądzu, to pobrzmiewa u mnie kredytowa teoria pieniądza. Wreszcie gdy piszę o ziemi, to chodzi mi o rynek nieruchomości (lub o to, co David Harvey nazywa „urbanizacja kapitału”). Za pomoca przedefiniowanych pojęć Polanyi'ego tworzę własną teorię zarówno genezy, jak i natury kapitalizmu. Twierdzę, że kapitalizm w szerokim tego słowa znaczeniu opiera się na dwóch z trzech towarów fikcyjnych: na wyalienowanej pracy ( $z$ definicji niewolnej) oraz na pieniądzu kredytowym. Tak rozumiany kapitalizm jest tak stary jak znane nam społeczeństwa osiadłe, czyli ma kilka tysięcy lat. Ale kapitalizm w wąskim tego słowa znaczeniu opiera się jeszcze na trzecim filarze: nieruchomościach. Moment jego narodzin to ostatnie dekady dziewiętnastego wieku. Taka jest najbardziej elementarna teza postawiona w Kapitalizmie. Została ona wyłożona w krótkim wstępie zatytułowanym „Legenda”, a następnie wielokrotnie powtórzona na kartach książki. Oczywiście części tej układanki nie są moim wymysłem i nigdzie nie piszę, że tak jest. Takie stwierdzenie byłoby absurdalne.

Całość, która wyłania się z tak poukładanych części, daje nową odpowiedz na dwa fundamentalne pytania: czym jest i skąd wziął się kapitalizm. Modyfikując pojęcia wzięte od Polanyi'ego, jestem bowiem w stanie połączyć ze sobą dwie, wydawałoby się niezależne i sprzeczne wobec siebie, dyskusje ostatnich dekad: pierwszą, która wskazuje na antyczne korzenie kapitalizmu (coś, co na przykład Jack Goody nazywa „kapitalizmem przed kapitalizmem”) oraz drugą, dyskusję o „urbanizacji kapitału”, zainicjowaną w dużej mierze przez Harveya. Novum tego argumentu polega też na tym, że zwykle teorie genezy kapitalizmu skupiaja się albo na roli pieniądza (kapitału), albo pracy. Innymi słowy, teorie tłumaczące wyjątkowość gospodarczą Zachodu albo akcentują ścieżki kapitałochłonne (capital-intensive), jak większa innowacyjność technologiczna czy też wynalazek finansowości, albo trajektorie pracochłonne (labor-intensive), jak teoria „rewolucji pracowitości” (industrious revolution) propagowana m.in. przez Jana de Vriesa. Moja teoria pokazuje, że kluczowym czynnikiem, który umożliwił Zachodowi wyjście na pozycję lidera światowej gospodarki, był trzeci, zupełnie pomijany element: ziemia. Oczywiście idę tutaj tropem wyznaczonym głównie przez tzw. kalifornijską szkołę w historii gospodarczej, a zwłaszcza dorobek Kennetha Pomeranza. Ale 
nie powtarzam verbatim tez Pomeranza, tylko dołączam do nich analizę transformacji od tzw. przestrzeni absolutnej do tzw. przestrzeni relacyjnej, wyniesiona od takich autorów jak Harvey czy Neil Smith. To wszystko pozwala mi też odejść od wciąż najbardziej popularnej, a wywodzącej się w dużej mierze od Immanuela Wallersteina, wizji kapitalizmu, która za moment jego narodzin uznaje epokę nowożytną (szesnasty i siedemnasty wiek), a za miejsce jego narodzin - Europę Zachodnia.

Nie za bardzo rozumiem, dlaczego Sowie tak bardzo zależy na tym, aby pokazać, że Kapitalizm nie jest oryginalnym dziełem. To trochę tak, jakby zarzucać kuratorce wystawy, że obrazy, które wybrała, były już gdzieś wcześniej pokazane. Oczywiście można taki zarzut postawić, ale wynika on z niezrozumienia roli kuratorki sztuki. Przecież wartością dodaną pracy kuratorskiej jest nowe zestawienie istniejących już dzieł oraz nadanie im innego znaczenia poprzez pracę z kontekstem. Jeśli czegoś kuratorce brakuje, to zamawia ona też nowe prace. Jednakże większość wykorzystywanych na wystawie prac zwykle powstała wcześnie i często ktoś już gdzieś je zobaczył. Czy to oznacza, że takie wystawy nie sa „,prawdziwie oryginalne”? Gdyby całość Kapitalizmu była moim autorskim wymysłem, to nie musiałbym w książce używać przypisów. A przypisów jest tu ponad tysiąc pięćset. Dlatego też bardzo wyraźnie zaznaczam, co od kogo biorę, co zmieniam, a co dodaję. To, co jest moim wkładem zasadniczym, wyjaśniłem powyżej, ale nie oznacza to, że na tym kończy się moja twórcza praca. Drobnych interwencji teoretycznych jest w tej książce więcej. Nie jestem oczywiście prekursorem w kwestii tezy, że pierwsi Piastowie handlowali niewolnikami. Buduję swoją analizę tego zjawiska głównie na badaniach archeologów Michała Kary i Przemysława Urbańczyka, a także Dariusza Adamczyka czy Marka Jankowiaka. Ale żaden z nich nie łączył handlu dalekosiężnego z tym, w jaki sposób instytucja niewolnictwa stała u podstaw ustroju państwa polskiego we wczesnym średniowieczu. O to spierali się Karol Modzelewski i Karol Buczek, ale wzrok obydwu skierowany był w stronę Lacińskiego Zachodu, a nie w stronę świata islamu. Łączę więc te dwie dyskusje (nie zrobiono tego wcześniej), a także niuansuję pewne zagadnienia i na przykład - poddaję krytyce analizę roli srebra w budowaniu podwalin państwa przez Mieszka, jaką można znaleźć u Urbańczyka.

Ton recenzji Sowy postawił mnie niestety w kłopotliwej sytuacji, w której muszę się z tych kwestii tłumaczyć. Pozwolę sobie zatem na jeszcze jeden przykład, który również dobrze ilustruje, na czym w moim przekonaniu polega praca z teoria. Moja narracja na temat genealogii kapitalizmu zostaje przedstawiona na czterech tablicach (patrz poniżej). Stworzyłem je w oparciu o dane makroekonomiczne opracowane przez Angusa Maddisona. Za ich pomoca dokonuję de-okcydentalizacji teorii Giovanniego Arrighiego. Sowa pewnie by napisał, że skoro używam danych Maddisona, które są ogólnodostępne, to nie ma tu nic oryginalnego. Jednak nawet sam Arrighi używał tych danych, nie tylko zresztą on. Ale nikt dotychczas nie podjął się przetłumaczenia kategorii jakościowych (hegemonie kapitalizmu) używanych przez Arrighiego 
na kategorie ilościowe. Twierdzę, że można ilościowo „pokazać” teorię Arrighiego, przyglądając się rozwojowi gospodarczemu przez pryzmat wzrostu PKB per capita. Następnie tłumaczę, że jest to błąd, opisuję dlaczego ta statystyka wypacza nasze rozumienie historii gospodarczej i oferuję własną alternatywę - procentowy udział poszczególnych bloków (a nie państw narodowych) w globalnym PKB. Znów, nie ja wymyśliłem te kategorie, ale to ja używam ich do krytyki Arrighiego. Wykonuję też pracę nad pojęciami Maddisona. Jego dane dotyczą bowiem państw narodowych oraz większych kategorii geograficznych, takich jak „Bliski Wschód” czy „byłe ZSSR”. Są to kategorie ukute w czasie zimnej wojny i odnoszące się do zimnowojennych pojęć geograficznych. Dlatego konstruuję inne jednostki przestrzenne - takie jak blok atlantycki (USA i Wielka Brytania) oraz blok kontynentalny (Włochy, Holandia, Francja, Niemcy). Innymi słowy, przekładam pewne wnioski natury teoretycznej na język analizy ilościowej. W tym przypadku wspinam się więc na ramiona Angus Maddisona po to, aby pokazać mankamenty teorii Arrighiego, a dzięki temu przedstawić, na czym polega problem okcydentalizmu oraz nacjonalizmu metodologicznego.

\section{Poszerzanie pola widzenia}

Co istotne, wszystko to, co opisałem powyżej, zostało przedstawione w Kapitalizmie. Ale zostało przedstawione subtelnie, na marginesie rozważań, które uważam za istotniejsze. Nie ma tam rozdziału zatytułowanego „Mój osobisty wkład w teorię kapitalizmu”. Zakładam, że czytelnik wyrobiony, który zna tych autorów i ich dorobek, będzie w stanie sam zauważyć, na czym opierają się moje interwencje; a czytelnik laicki zauważyć tego nie musi, bo nie to jest tutaj sednem sprawy. Jako że Sowa zarzucił mi pretendowanie do niezasłużonej kategorii oryginalności, a zarzut ten wrócił do mnie kilka razy (m.in. podczas spotkań autorskich czy też w jednej recenzji), zostałem wywołany do tablicy i dlatego tutaj, raz jeszcze, referuję omówione już problemy. O ile sam jestem zadowolony np. z tego, jak udało mi się za pomoca krytyki Arrighiego i danych Maddisona stworzyć cztery wykresy, które pokazuja przejście od okcydentalnej do nieokcydentalnej teorii kapitalizmu, o tyle jestem przekonany, że to nie moja osoba jest tutaj najważniejsza. Postać autora książki jest w niej niejako „ukryta”, gdyż ma ona spełnić dwa podstawowe cele, które ze mna jako osobą mają niewiele wspólnego. Pierwszy cel, jak ujął to Andrzej W. Nowak (podczas poznańskiej dyskusji wokół książki), jest performatywny, a drugi czysto akademicki. Cel performatywny to przeprowadzenie deokcydentalizacji polskiej humanistyki, a cel akademicki to wyłożenie własnej narracji na temat tego, czym jest i skąd wziął się kapitalizm. Mam wrażenie, że Sowa (pisząc na przykład: „Nie przeczę, że poszczególne spostrzeżenia czy propozycje Pobłockiego dotyczące znaczenia władzy państwowej dla działania kapitalizmu mogą być nowe i oryginalne, jednak trudno tu 
mówić o jakiejkolwiek reorientacji całościowej ramy”) nie za bardzo widzi różnicę między tymi dwoma sprawami. A jest to różnica zasadnicza.

Cel performatywny zostaje osiagnięty nie przez to, co mówię, ale przez to, jak zostaje to powiedziane. Jak pisał klasyk medioznawstwa i teorii komunikacji, medium is the message. Dlatego konstrukcja tej książki jest ścisła konsekwencją tezy, która jest w niej stawiana. Bowiem można oczywiście napisać: „Zachód nie jest wyjątkowy” albo „Zachód nie jest lokomotywą historii”, albo „Zachód nie wynalazł kapitalizmu”. Ale co z tego? Mówienie rzeczy, które ida pod prąd zbiorowych przekonań, jest jak wołanie na puszczy. Nie wystarczy tego powiedzieć, trzeba to pokazać. Długie ksiażki pisze się właśnie po to, żeby wyjaśnić coś, czego nie da się zakomunikować jednym zdaniem. Lektura każdej książki jest procesem - jeśli bierzemy do ręki powieść, to przechodzimy (najczęściej podążając za transformacją głównej bohaterki) przez jakieś (intelektualne czy emocjonalne) doświadczenie. Przeczytawszy ostatnie zdanie, jesteśmy kimś innym, niż byliśmy w chwili, gdy otwieraliśmy książkę po raz pierwszy. Czytanie to podróż. W tym sensie nie ma znaczenia to, że książka prowadzi nas przez coś, co jest nam już częściowo znajome. Liczy się doświadczenie, które zostaje w ten sposób wygenerowane. Jest nawet lepiej, jeśli podróżujący widzą za oknem częściowo oswojony krajobraz, bo dzięki doświadczeniom ,wykuratorowanym” przez autora patrzą na to wszystko pod nowym kątem. Innymi słowy, jeśli elementy potrzebne do de-okcydentalizacji humanistyki były już dostępne (a spora część książek, które cytuję, została nawet przetłumaczona na język polski), ale nie wyciągnięto z nich należytych wniosków, to znaczy to, że te rzeczy nie były powiedziane właściwie.

Przeniesienie teorii de-okcydentalizacji nauk społecznych (najbardziej skrupulatnie przedstawionej chyba przez Jacka Goody’ego) do konstrukcji książki akademickiej uważam za mój największy wkład. Na tym też polega różnica między dorobkiem Goody’ego a Kapitaliżmem. Goody dokonuje de-okcydentalizacji w sposób klasyczny. Bierze kolejno na warsztat każdy z możliwych mitów o zachodniej wyjątkowości i krok po kroku go obala, krytykując przy okazji takie postaci jak Max Weber, Norbert Elias czy Fernand Braudel. Książki Goody'ego są od lat dostępne po polsku. Ale zdaje się, że nikt - lub prawie nikt - ich nie przeczytał. A na pewno nikt nie wyciągnął z nich należytych wniosków. Gdybym powielił strategię Goody'ego i napisał książkę, której konstrukcja byłaby podobna na przykład do konstrukcji jego Kradzię̧y historii (gdzie rozdziały sa tematyczne), to wtedy Sowa zarzuciłby mi pewnie, że „to już było u Goody'ego”. I w tym przypadku miałby rację. Uznałem więc, że należy zrobić kolejny krok - bowiem demaskacja mitów to dopiero oczyszczenie gruntu pod coś poważniejszego. Goody pokazuje, dlaczego Zachód nie był wyjątkowy, ale nie oferuje alternatywnej wizji rzeczywistości, nie opisuje świata z perspektywy chińskiej czy albańskiej. A moją ambicja jest raczej to drugie (i dlatego na przykład w rozdziałach 13-16 pokazuję, jak reorientacja z łacińskiego Zachodu na świat islamu pozwala na nowo opowiedzieć historię o początkach 
państwa polskiego). Zwłaszcza że polska czytelniczka może spokojnie sięgnąć do książek Goody'ego, jeśli chce dokładniej zgłębić któryś z wątków pojawiających się w Kapitaliæmie.

Tego rodzaju wysiłek intelektualny dostrzegła m.in. Kinga Dunin. Pisze ona w swojej recenzji: „I to - zmiana punktu widzenia - z narodowo- i europocentrycznego na globalny naprawdę się autorowi powiodło. Nie jest to tylko kwestia deklaracji, bo takich we współczesnych naukach społecznych nie brakuje: należy dostrzegać perspektywę globalną, uniwersalizm Zachodu, nie jest wcale taki uniwersalny itp. Książka Pobłockiego jednak naprawdę osiaga ten efekt, zmienia, przynajmniej na czas lektury, punkt widzenia czytelnika" (Dunin 2018). Taki punkt widzenia nie powstaje sam z siebie. Weźmy na przykład część pierwszą książki. Zaczyna się ona od współczesnego Detroit - uznawanego za jedno z pierwszych miast, w których rodzi się ,postkapitalizm”. Wnioskiem, jaki wyciagam z wyjazdu do Detroit oraz z analizy tego miasta, jest to, że nie można zrozumieć trajektorii jego zmian bez spojrzenia szerszego - w sensie dosłownym. Czytelnik akademicki zrozumie, że zamiast mówić o Detroit jako o „miejscu”, proponuję mówić o nim jako o „przestrzeni” (to dwa fundamentalne, ale nieco odmienne pojęcia w studiach miejskich). Czytelnik nieakademicki może odniesień do debat teoretycznych nie zauważyć, doświadczy natomiast stopniowego poszerzania horyzontu poznawczego.

Bo właśnie na nieustannym poszerzeniu pola widzenia opiera się struktura pierwszej części Kapitaližmu. Zaczynamy od Detroit i od rzekomych problemów, z którymi boryka się to miasto i które podobno stanowią o jego „przekleństwie” (lub, jak powiedzieliby badacze przywiązani do paradygmatu „miejsca”, jego genius loci). Ale okazuje się, że nie da się mówić o Detroit, nie mówiąc o Ameryce w ogóle. A potem, że nie można mówić o finansjalizacji w USA, abstrahując od Chin, Niemiec i Japonii. A potem okazuje się, że aby uzyskać całościowy obraz Detroit i Ameryki, należy też dołączyć do analizy wybrane kraje Afryki, Europy Wschodniej oraz niepozorne wyspy na Karaibach. Zaczynamy więc wywód od jednego miejsca, a kończymy w zasadzie na całym świecie. Taki intelektualny zooming out rozpoczyna się pod koniec rozdziału 1, a kończy się w rozdziale 7. Następnie, w ostatnich rozdziałach tej części, powracamy do USA, ale już nie do Detroit, tylko do Nowego Jorku. I wracamy z całym bagażem wiedzy, który wygenerowała ta podróż. Innymi słowy, o ile na Detroit patrzyliśmy z perspektywy lokalnej (która jest w rozdziale 1 jedyne poddawana dekonstrukcji), tak na Nowy Jork patrzymy z perspektywy globalnej i przez to pozbawionej okcydentalizmu. Dzięki tej podróży „palcem po mapie”, od Detroit przez cały świat do Nowego Jorku, możemy inaczej spojrzeć na te dwa amerykańskie miasta. Dlatego w finalnym rozdziale pierwszej części książki widać już wyraźnie, że do Nowego Jorku o wiele lepiej pasuje teoria i analiza zaproponowana przez Roberta Fitcha (zupełnie zapomniana i niedoceniania postać w studiach miejskich), a nie znana i wciąż popularna optyka Saskii Sassen, która proponuje teorię „miasta globalnego”, postindustrialnego etc. Tutaj też widać, jak cel performatywny książki („wykuratorowanie” 
pewnego doświadczenia intelektualnego) przekłada się na cel akademicki (czyli zaoferowanie nowych pojęć, czy też nowych teorii).

Tego rodzaju podejście formalne spotkało się z największym oporem ze strony „wyćwiczonych” akademicko recenzentów. Z jednej strony twierdzono, że struktura książki jest chaotyczna (pisali tak nie tylko historyk Kamil Śmiechowski, ale też Łukasz Moll i Szymon Grela), a z drugiej zauważano, że atutem książi jest erudycja autora. Właściwie nie zgadzam się ani z zarzutem, ani z komplementem. Struktura książki jest konsekwencja przyjętej przeze mnie optyki teoretycznej. Twierdzę, iż język humanistyki oraz będący jego pokłosiem nasz potoczny (odruchowy wręcz) światopogląd zamknięte są w pojęciach temporalnych - patrzymy na świat przez pryzmat czasu. Proponuję w zamian spojrzenie na świat przez pryzmat przestrzeni. Znów, nie jestem pierwszą osobą, która o tym mówi - w ciagu ostatnich kilkudziesięciu lat trąbiło się o tym nieustannie. Ale, podobnie jak z okcydentalizmem, łatwo się mówi, jednak o wiele trudniej jest to wdrożyć. Współczesna humanistyka naszpikowana jest metaforami przestrzennymi - powraca w niej teza, że „przestrzeń się liczy” (space matters), pojawiają się odniesienia do kartografii, miasta i urbanizacji, pisze się o mapowaniu tego czy owego. Ale te metafory niewiele daja - są najczęściej zasłoną dymną dla autorów, którzy nie rozumieją, skąd naprawdę się one biorą i jakie są tego realne konsekwencje. W Kapitalizmie, używając szeregu przykładów pokazuję, jak rozumieć owo przewartościowanie. Przede wszystkim omawiam mankamenty pojęć temporalnych (pojęcia można przyrównać do okien, przez które patrzymy na świat) i oferuję w zamian pojęcia przestrzenne. Ale radykalizm tego postulatu widoczny jest dopiero wtedy, gdy zrozumiemy, że „myślenie przez pryzmat czasu” dotyczy również struktury książek. To nie przypadek, że historycy prezentują swój materiał empiryczny chronologicznie - piszą książki od „początku” do „końca”, od epoki najdawniejszej do współczesności. Książka, która postulowałaby odrzucenie optyki temporalnej na rzecz optyki przestrzennej, a jednocześnie miałaby podręcznikową strukturę narracyjna, byłaby nie tylko intelektualnie nieszczera, ale też w moim przekonaniu po prostu nieudana.

Nie tylko zresztą w moim przekonaniu - w swojej recenzji zwraca na to uwagę również Adam Klewenhagen. Pisze on:

Specyficzna forma w jakiej [argumentacja - KP] zostaje przedstawiona - 19 rozdziałów, które nie składaja się w systematyczny wywód, typowy dla pozycji naukowych (od przedstawienia problemów, przez zarysowanie stanowiska autora, po argumenty, polemiki i wnioski) - nie jest w żadnym razie wyborem przypadkowym. Przeciwnie wiąże się ona ściśle z zastapieniem myślenia o historii myśleniem o przestrzeni. Linearna struktura wywodu naukowego odpowiadałaby linearnej strukturze czasu historycznego (w jego ewolucyjno-teleologicznym rozumieniu, które jest głównym celem ataków Pobłockiego). Obie składają się z „etapów”, z których jedne stanowią 
podstawę dla kolejnych, tworząc układy czy to przesłanek i wniosków, czy przyczyn i skutków. Tymczasem kartografia, jako myślenie przestrzenia, każe etapy zastapić „warstwami”, zachowującymi autonomię, a mimo to wchodzącymi w (cokolwiek tajemnicze) związki. Nie chodzi oczywiście o to, że Pobłocki odrzuca formułowanie argumentów albo uparcie przeczy istnieniu czasu - chodzi o to, że również na poziomie kompozycji swojego tekstu systematycznie odwraca on uwagę od czasowo-linearnego sposobu porządkowania świata. Forma książki nie jest wyłącznie fantazyjna propozycja podania ani wyrazem niechlujstwa, a jej zakres tematyczny, o którym była mowa na początku, jedynie wyrazem skali przedsięwzięcia. To, na co wskazują rozmaite i liczne poruszone w niej wątki, to bowiem właśnie metonimiczne znaczniki wspomnianych warstw, które odsłania perspektywa „globalnego materializmu” (Klewenhagen 2018)

Cieszę się, że Klewenhagen zwrócił na to uwagę, choć nie uważam, aby Kapitaliżm składał się z warstw. Z rozdziałów-warstw składa się Tysiac platean Gilles’a Deleuze’a i Feliksa Guattariego. Idea warstw geologicznych jest mi jednak obca - w książce (Pobłocki 2017, 58) przytaczam obraz Czerwona kawaleria Malewicza, na którym widzimy, jak dynamiczna zmiana, zachodząca w czasie, „odkłada się” w przestrzeni za pomocą martwych w zasadzie warstw geologicznych. Kapitalizm nie jest książką o przestrzeni, ale raczej próbą spojrzenia przez pryzmat przestrzeni na zmianę społeczną i ekonomiczną. Dlatego postanowiłem zastanowić się, jak przenieść ideę mapy (czyli przestrzennego sposobu organizowania wiedzy) na formułę książki akademickiej. Stąd coś, co dla czytelnika przyzwyczajonego do narracji podręcznikowej może wyglądać na „skakanie z tematu na temat”, jest precyzyjnie „wykuratorowana” mapa.

W tym sensie rację ma Agata Czarnacka, że „na ponad 600 stronach z tablicami i przypisami ma zmieścić się cały świat”. Jeśli spojrzymy na mapę świata, zobaczymy jednocześnie i Japonię, i Meksyk, Polskę oraz USA. Każda osoba korzystająca z mapy doświadcza swoistej podróży „palcem po mapie” - wędruje z miejsca do miejsca. Taką wędrówka jest również ta książka - to autor wodzi po mapie palcem, a czytelnicy podążaja za nim. Oczywiste jest to, że nie idziemy wszędzie, bo przecież na żadnej mapie nie ma „wszystkiego”. To, co zostaje przemilczane, niejednokrotnie jest tak samo istotne jak to, co na mapie się pojawia. Uważam, że tego rodzaju sposób narracyjnej organizacji książki akademickiej jest bliższy faktycznemu „myśleniu przez pryzmat przestrzeni”, które postuluję. Co więcej, logika miasta kapitalistycznego (czy też logika nierównego rozwoju, jak to opisuję za Neilem Smithem i innymi) osadza się na tym, że obok siebie występują tu zaskakujące i na pierwszy rzut oka nieprzystające do siebie rzeczy, osoby czy zjawiska. Miasto współczesne - to oczywiście banał - jest „pełne kontrastów”. I właśnie na kontrastowym zestawianiu ze sobą tych (intelektualnych) zjawisk opiera się spacer palcem po mapie globalnego kapitalizmu, na który zabieram czytelników. 
Takie poszerzanie pola widzenia jest często odbierane jako ćwiczenie z erudycji (to właśnie przed moją rzekomą erudycją Sowa „chyli czoło”). Nic bardziej mylnego - nie chodzi tutaj o to, aby pokazać, że oprócz tego, iż przeczytałem co nieco o Detroit, to wiem też coś o Angoli oraz Chinach. Figurę akademickiego omnibusa uważam osobiście za coś bardzo odpychającego, a wręcz niebezpiecznego. Najlepiej chyba problem z tego rodzaju podejściem do pracy intelektualnej wyraził Gilles Deleuze, którego duch również unosi się nad stronami Kapitalizmu. Deleuze w ostatnim wywiadzie, którego udzielił przed śmiercią, zwierzył się, że przerażaja go osoby takie jak Umberto Eco. Sa jak maszyna - naciśniesz przycisk, a zaraz popłynie elokwentna narracja na dowolny temat. Postaci takie jak Eco - erudyci, którzy przeczytali wszystko, co było do przeczytania - są ikonami myślenia o pracy intelektualnej jako o akumulacji wiedzy (i przez to akumulacji władzy). A akumulacja wiedzy ma na celu dystynkcje - odróżnienie „mądrych” od „głupich”. Deleuze twierdził, że nie interesuje go gromadzenie informacji - do każdego projektu stara się podejść tak, jakby nic wcześniej nie wiedział. Wypowiedz ta, gdy usłyszałem ją na studiach, skleiła mi się z innym ważnym dla mnie zdaniem: krótka piosenką zespołu Dezerter pod tytułem Bzdury. Leci ona tak: „Głupi ludzie wierza w głupie bzdury; mądrzy ludzie wierzą w mądre bzdury”. Jeśli projekty intelektualne Deleuze’a są, jak pisał Foucault we wstępie do Anty-Edypa, podręcznikiem do ,antyfaszystowskiego życia", to postaci takie jak Eco sa faszystami (czyli podmiotami zakochanymi we władzy) ukrytymi w tweedowych marynarkach.

Pracowałem nad tą książką przez dziesięć lat, więc siłą rzeczy jest tam sporo informacji, które w tym czasie gdzieś zdobyłem. Ale - mam nadzieję, że jest to jasne dla czytelników - nie chodzi w niej o to, by popisywać się erudycja, by zorganizować dla odbiorców ciekawy intelektualny spacer. Fragment Kapitalizmu, z którego osobiście jestem najbardziej zadowolony, to rozdział 8, zatytułowany „Minsky w Albarado”. To tam pojawia się Angola, RPA oraz Albania. Lubię go jednak nie ze względu na to, co w nim jest, ale jaką funkcję spełnia w całej konstrukcji książki. Po tym, jak zaczynamy podróż od Detroit, a następnie przez sześć kolejnych rozdziałów czytamy o Ameryce, finansjalizacji, derywatach, krachu na rynku subprime, jest to pierwszy moment, w którym czytelnik faktycznie doświadcza deokcydentalizacji. Okazuje się, że to, co wydawało nam się immanentną cechą Zachodu, wcale nią nie jest. I dowiadujemy się, że to Ameryka jest ,z tyłu” takich krajów jak Albania czy Angola. Intelektualna wyprawa do tych krajów nie jest incydentalna - to, że właśnie w tym momencie narracji zbieram czytelników do Albanii czy Angoli, nie jest kwestia przypadku, ale spełnia ważny cel: w ten sposób moge pokazać, jak przestać patrzeć na świat przez pryzmat wyjątkowości Zachodu. Dlatego robię to w rozdziale 8, a nie w rozdziale 4 czy 13.

Taki jest zatem performatywny aspekt obietnicy „re-Orientacji”, złożonej w pierwszym zdaniu książki. Jaki jest aspekt akademicki? Otóż dotyczy on na pracy nad pojęciami, w tym pracy nad samym pojęciem „reorientacji”. Biorę je, oczywiście, od Andrego Gunder Franka, 
który pisał dwie dekady temu o reORIENTacji. Ale używam go inaczej - tzn. gram na podwójnym znaczeniu tego słowa. Po pierwsze chodzi o zmianę kierunku patrzenia (nie tylko o pokazanie politycznego wymiaru naszej ciekawości, ale też o zaprezentowanie, jak można inaczej patrzeć na świat, jeśli nie patrzy się na niego przez pryzmat Zachodu). Drugie znaczenie to nagła zmiana, zryw. To właśnie jest już moim wkładem i wpisuje się w projekt budowania siatki pojęć, za pomoca których można patrzeć na świat przez pryzmat przestrzeni. Chodzi o to, że historia to dla mnie nie tylko długie trwanie, ale też, a może przede wszystkim, proces nieciagły. Tradycyjnie zakłada się na przykład, że kapitalizm w jakiś sposób wyewoluował z feudalizmu, a ten z ustroju antycznego. Główkowanie polega na próbach wyodrębnienia kluczowego elementu, który uruchomił zmianę. Pojęcie reorientacji pokazuje, że poszczególne epoki nie wynikają z siebie - zmiana nie przychodzi z wewnątrz (słynne „sprzeczności” jakiegoś ustroju, które dialektycznie rodzą nowy ustrój), ale z zewnątrz. W tym sensie nie mamy do czynienia z dynamiką „zacofania/doganiania”, ale właśnie ze zmianą na poziomie globalnym, w której praktycznie wszyscy próbują się odnaleźć. Przykład, nad którym najdłużej się pochylam, to transformacja z ustroju plemiennego w państwowy; ale transformacji jest (jak widać chociażby po przejrzeniu tego hasła w indeksie) więcej - z feudalizmu do kapitalizmu czy z gospodarki planowej do rynkowej. A zatem łączę pojęcie reorientacji z pojęciem transformacji (któremu też nadaję inne znaczenie, bo z reguły tym słowem opisuje się przejście z PRL do III RP), a także - na zasadzie negacji - z pojęciem genezy. To właśnie idea genezy jest królową pojęć temporalnych, dlatego poświęcam dużo czasu na jej omówienie, proponuję ideę „państwowej genezy państwa” (aby pokazać granice użyteczności tego pojęcia) oraz przekierowuje poszukiwania „miejskich korzeni [współczesnego] kapitalizmu” w stronę sformułowania przestrzennej teorii jego funkcjonowania oraz narodzin.

Zatem podróż, w którą zabieram czytelników, jest równocześnie podróżą przez tego rodzaju pojęcia. Reorientacja omówiona powyżej jest tylko przykładem. Większość $\mathrm{z}$ interesujących mnie pojęć znajduje się w indeksie, który pełni funkcję przewodnika po „pojęciowym” aspekcie tej książki. A zatem struktura Kapitalizmu - polifoniczna i na pewno nietypowa, jeśli chodzi o dzieła akademickie - jest konsekwencją nałożenia się na siebie czterech elementów. Po pierwsze, hołdu dla Wielkiej Transformacji Polanyi'ego (stąd książkę można czytać jako omówienie roli przestrzeni, pieniądza oraz pracy w kapitalizmie, zarówno współczesnym, jak i historycznym). Po drugie, podróży „palcem po mapie”, której celem jest de-okcydentalizacja światopoglądu czytelników. Po trzecie, budowy sieci pojęć, które stanowia alternatywę dla myślenia temporalnego i pokazuja, jak patrzeć na świat przez pryzmat przestrzeni. Czwartą sprawą, która miała duże znaczenie dla tego, jak został napisany Kapitalizm, jest analfabetyzm ekonomiczny. Ta kwestia wymaga osobnego omówienia. 


\section{Bądźmy wzniośli, ale nie bełkotliwi}

Kapitalizm skierowany jest do dwóch rodzajów odbiorców. Pierwszy to czytelnik wyrobiony, który zna Goody’ego, Franka, Graebera i Harveya, który jest w stanie docenić moja reinterpretację teorii Polany'iego i tak dalej. Czytelnikiem drugim jest laik. Osoba, która jest jednym z milionów „analfabetów ekonomicznych” (to też nie jest moje pojęcie). Znów, łatwo jest napisać tekst-manifest, w którym krytykuje się hermetyczność języka ekonomii, wrzuca parę złośliwości wobec neoliberalizmu oraz postuluje demokratyzację wiedzy i dyskursu. Po czym artykuł taki wysyła się do jednego z „radykalnych” pism akademickich, których wydawcy żądają kupy pieniędzy za możliwość przeczytania tego tekstu (na przykład dostęp do jednego - powtarzam jednego - z tekstów publikowanych w świetnym skądinąd piśmie Antipode. A Radical Journal of Geography kosztuje dziś 38 funtów). Aby pokazać, że idzie się z duchem czasu, trzeba taki postulat okrasić jakimś dobrym żargonem, który pozwoli na cytowanie tych, których akurat w danej chwili wypada (tzn. należy) cytować.

Efekt? Efektem jest to, że przeciętnie tego rodzaju teksty czyta 10 osób ${ }^{1}$. Najprawdopodobniej będzie to i tak ta grupa, która nas zna i lubi, a celem tekstu będzie potwierdzenie naszej przynależności do niej. Tak nikły zasięg odbioru nie wynika tylko z faktu, iż dostęp do tekstów akademickich jest ograniczony; jest on również pokłosiem tego, iż większości tekstów akademickich nie da się czytać. Żargon bierze w nich górę nad treścią. Zwykle takie teksty, których autorzy chowają się za trudnymi słowami lub cytatami z kogoś innego, po prostu są dowodem na to, że sami autorzy nie mają wiele do powiedzenia. Publikacje tego typu są tylko rytualnym powtórzeniem tego, co należy powiedzieć. Po kilku latach, gdy używany w nich język ulega przeterminowaniu, czasami trudno jest nawet zrozumieć, o co chodziło. W lewicowych kręgach akademickich świata anglosaskiego jedną z tych rzeczy, które są rytualnie powtarzane, jest właśnie postulat udemokratycznienia debaty akademickiej, w tym dyskusji o ekonomii. Ale nikt prawie nie widzi sprzeczności między formą a treścią. Wystarczy spojrzeć na teksty wielu teoretyków postkolonialnych, którzy używają bardzo trudnych słów do tego, aby mówić banały. Powszechna niechęć do tzw. lewicy kawiarnianej, kanapowej czy też kawiorowej jest w tym sensie zrozumiała. Nie trzeba być geniuszem, by zobaczyć, że coś tu nie gra: postulat o radykalnej demokratyzacji wyrażony w niedemokratyczny sposób jest po prostu rażąco nieszczery.

Stąd wyzwanie, jakie stoi przed współczesną akademia, polega na takim zreformowaniu języka nauki, aby, z jednej strony, pozwalał on na mówienie rzeczy nowych (czyli np. na wypracowywanie nowych pojęć, co jest w moim przekonaniu jednym z ważnych zadań humanistyki), ale z drugiej strony - nie był hermetyczny. W Kapitalizmie zastosowałem kilka

\footnotetext{
${ }^{1}$ http://www.straitstimes.com/opinion/prof-no-one-is-reading-you
} 
metod udemokratycznienia tekstu. Po pierwsze, każde pojęcie jest tam krótko wyjaśnione. Przedstawiam też zwięźle każdego autora, na którego się powołuję. Kiedyś czytałem rozmowę z pewnym polskim profesorem, który zżymał się, że gdy profesor amerykański wygłasza wykład, to tłumaczy, że Arystoteles był greckim filozofem. „Przecież każdy wie, kim był Arystoteles. A przynajmniej powinien wiedzieć" - denerwował się. To właśnie jest bardzo niedemokratyczny gest - nikomu majestatu nie ubędzie, gdy przedstawi Arystotelesa, a osoby, które słyszą o nim po raz pierwszy, nie będa miały poczucia, że ktoś daje im do zrozumienia (oczywiście podprogowo), iż znajduja się w niewłaściwym gronie, bo brakuje im „elementarnej” wiedzy. Profesor starszej daty, który czytał Kapitalizm, denerwował się, że na każdym kroku wyjaśniam aparat teoretyczny, którego używam. „Przecież każdy wie, co to jest teleologia" - mówił. Gdy przedstawiłem mu powód zastosowania przeze mnie tego zabiegu, odparł, że „książki przecież pisze się dla kolegów”. Pozwalam sobie nie zgodzić się z takim podejściem do pracy akademickiej. Kapitaliźm jest efektem próby napisania takiej książki, z której korzystać będą mogli nie tylko moi koledzy (i koleżanki) po fachu. Uważam, że publikowanie takich prac jest naszą - intelektualistów publicznych - misją i naszym obowiązkiem.

Z tego samego powodu książka podzielona jest na rozdziały o niemalże identycznej długości oraz o bardzo podobnej strukturze (każdy rozdział ma trzy części). Dzięki temu łatwiej jest przeczytać tak długi tekst. Istotę tego zabiegu formalnego najlepiej widać na przykładzie seriali. Gdybyśmy nie wiedzieli, że każdy kolejny epizod będzie trwać tyle samo (powiedzmy 45 minut), to tzw. binge watching, oparte na mechanizmie „a, jeszcze jeden odcinek!”, nie byłoby możliwe. Zatem czytelnik, który wejdzie już w narrację Kapitaliz̨mu, który rozpozna rytm tej książki, może też łatwo zaplanować sobie lekturę. Rozdziały zostały napisane tak, by finał każdego z nich był jednocześnie zapowiedzią (a czasem małym cliffhangerem) następnego; sporo wysiłku włożyłem więc w to, aby czytelnik nie chciał książki odkładać. Takich rzeczy może nie widać na pierwszy rzut oka, nie piszę też o nich wprost we wstępie właśnie dlatego, że zabiegi te maja zadziałać. Czytelnik, który mówi sobie: „a, mam chwilę, to przeczytam jeszcze jeden rozdział”, nie musi (a może nawet nie powinien) wiedzieć, dlaczego to robi. Dla mnie jednak jako dla autora ułatwienie lektury odbiorcom było bardzo ważnym celem - właśnie dlatego, że - raz jeszcze: na poziomie formalnym, a nie tylko na poziomie deklaracji - cel ten realizuje postulat demokratyzacji wiedzy. I dlatego recenzją, która sprawiła mi najwięcej radości, która potwierdziła to, że warto było napisać Kapitaliæm tak, jak został on napisany, był tekst Roberta Majewskiego, w którym padają słowa: „Czy ignoranta w sferze ekonomii - takiego jak ja - może zainteresować książka z tej dziedziny? Tak, jeśli jest to Kapitalizm Kacpra Pobłockiego. Książkę - a właściwie księgę - połknąłem jak powieść sensacyjną". 
Jednym z zarzutów, który powracał (czasem) na spotkaniach autorskich, zwłaszcza ze strony publiczności akademickiej, był właśnie zarzut dotyczący komunikacyjności tej książki. Często można usłyszeć twierdzenie, że jeśli coś się łatwo czyta, to znaczy, że nie jest to naukowe, a w najlepszym razie popularnonaukowe. Im tekst jest bardziej skomplikowany, tym wyżej plasuje się na drabinie naukowości. Nie za bardzo rozumiem, skąd ta teza. Przecież każdy, kto zajmuje się pisaniem, doskonale wie, że tworzenie tekstów, które łatwo się czyta, wcale nie jest łatwe. Być może jest nawet dokładnie odwrotnie - o wiele mniejszym wysiłkiem jest napisanie tekstu bełkotliwego, pełnego niejasności, niż takiego, w którym jakiś argument zostaje klarownie wyłożony. Symptomatyczne jest też to, że o ile w świecie akademickim często pada oskarżenie o „dziennikarskość” (tekst jest zbyt dobrze napisany, więc nie jest naukowy), o tyle nie zarzuca się naukowcom, że nikt ich nie czyta. A to, zważywszy na fakt, że nauka ma do spełnienia bardzo ważną rolę społeczna, jednak jest istotne. Warto też nadmienić, że podział na naukę komunikatywną i wsobną nie pokrywa się z podziałem na naukę anglosaską i polską. Gdy byłem studentem I roku MISH na Uniwersytecie Warszawskim, prowadzący zajęcia (jedyne zajęcia obowiązkowe) z semiotyki logicznej-Jerzy Pelc - mówił nam dokładnie to, co ja wyłożyłem powyżej. Pelc był przeczulony na punkcie tego, co w jego przekonaniu było plaga na polskiej akademii: nieklarowności myśli, która jego zdaniem maskowała po prostu nieznajomość rzeczy. Jeśli nie możesz czegoś wyrazić wprost, to znaczy, że nie wiesz, o czym mówisz. Całoroczny kurs Pelc zakończył napisanym na tablicy credo, które chciał, abyśmy wzięli sobie do serca. Brzmiało ono następująco: „Bądźcie wzniośli, ale nie bełkotliwi”.

\section{Polityczność pisania akademickiego}

Bełkotliwość języka akademickiego, a zwłaszcza języka ekonomii, jest w moim odczuciu nie tylko moda (jak uważał Pelc, który nie miał wielkiego szacunku do postmodernizmu). Nie tylko ma ona na celu udowodnienie, że jest się bardziej kompetentnym importerem czyjejś teorii (im trudniejsza teoria, tym większe umiejętności musi posiadać jej tłumacz na polskie realia), ale jest też elementem ideologii. We wstępie piszę wprost o analfabetyzmie ekonomicznym i o tym, że język ekonomii neoklasycznej służy raczej jako instrument sprawowania władzy niż narzędzie do wyjaśniania tego, jak działa świat. Dlatego, nieco prowokacyjnie, we wprowadzeniu powracam do paradygmatu „pozytywistycznego” oraz (też specyficznie przeze mnie przedefiniowanego) postulatu obiektywności, aby odejść od krytykowania tego, jak ktoś inny przedstawia świat, na rzecz próby jego nowego opisu. Można ten gest postrzegać jako porzucenie zmagań epistemologicznych na rzecz ontologicznych. Jest to, siła rzeczy, mission impossible, gdyż na pewno jakiś z aspektów mojej narracji okaże się błędny. Stąd właśnie wzięła się treść moich podziękowań - oczywiste jest to, że jeśli ja w którymś z elementów mojej 
układanki się mylę, to myli się wraz ze mną cała rzesza osób, których praca przyczyniła się do takiego postawienia sprawy.

Mógłbym równie dobrze zacytować tutaj Ernesta Gellnera, który zaznaczał, we wstępie do książki Plough, Sword and Book, że celem jego pracy jest:

\begin{abstract}
wyartykułowanie, w najbardziej klarownej i przez to może nieco przerysowanej formie, wizji historii ludzkości, która wyłania się [z istniejących badań], ale która nie została jeszcze wyraźnie sformułowana. Próba wyciagnięcia jej na powierzchnię nie wynika ze złudzenia autora, że znalazł oto klucz do prawdy i że już wie „jak było”. Autor tego wciąż nie wie. A teorie generalnie mają to do siebie, że nigdy nie są prawdą ostateczną. Jest tak tym bardziej w tym konkretnym przypadku - teorii, która odnosi się do nieskończonej liczby niezwykle złożonych faktów, których nie jest w stanie posiasść żaden indywidualny naukowiec. Wizja ta została tutaj przedstawiono po to, aby jej klarowne i stanowcze sformułowanie umożliwiło jej krytyczną ocenę (1989, 12-13).
\end{abstract}

Kapitalizm można skrytykować z wielu perspektyw. Można na przykład bronić okcydentalizmu, twierdząc, że teza Kennetha Pomeranza (za którym podążam), zgodnie z którą nic nie predestynowało świata anglosaskiego do wyprzedzenia Chin, jest wciąż kontrowersyjna i wytoczyć tutaj kontrargumenty. W polu polskiej akademii właśnie na pozycjach neomaltuzjańskich pozycjonuje się Adam Leszczyński w swoim Skoku w nowoczesność. Nie podzielam jego przekonań, ale szanuję ten wybór, gdyż jest to wciąż aktualna i popularna szkoła w historii gospodarczej. Można mi wypomnieć, że pomijam w Kapitalizmie niemal zupełnie rolę Ameryki Łacińskiej w ekspansji europejskiego kolonializmu (nie robi tego chociażby Jason W. Moore), że przemilczam rolę Indii w historii gospodarczej (a świetnie omawia ją Prasannan Parthasaranthi w Why Europe Grew Rich and Asia Did Not), że tylko sygnalizuje chińskie przygody z paliwami kopalnymi, a nie analizuje ich dogłębnie (jak robi to Mark Elvin w Retreat of the Elephants) i tak dalej. Można, jak robi to Piotr Kuligowski w swojej recenzji Kapitalizmu, stwierdzić, że moje odrzucenie „myślenia temporalnego” jest pochopne i przywołać m.in. pisarstwo Reinharta Kosellecka oraz jego filozofię procesu historycznego. Można, na co zwrócił uwagę Przemysław Czapliński (podczas poznańskiego spotkania), zastanowić się nad rolą ciagłości (na przykład w języku), skoro tak mocno akcentuję nieciagłość w historii gospodarczej. Można wreszcie, na co zwrócił uwagę Zbigniew Augustyński podczas spotkania w Płocku, zupełnie inaczej odczytać przygotowane przeze mnie tablice 8.1-8.4 i uznać, że progiem współczesności wcale nie jest rok 1870, po którym blok atlantycki wyprzedza pozostałych, ale rok 1830, w którym zaczyna się szybki marsz Wielkiej Brytanii oraz USA po globalną dominację. Żadnej z tych krytyk nie czyni Sowa, jedynie wypomina mi, że błędnie interpretuję autorów, których cytuję chyba najczęściej: Graebera, Arrighiego, Polanyi'ego czy Smitha. 
W tym sensie tekst Sowy wcale nie popycha debaty do przodu i jest w gruncie rzeczy dość konserwatywny (tj. zachowawczy). Widać to najlepiej, gdy zestawi się ją z recenzjami autorstwa Piotra Kuligowskiego oraz Jarosława Urbańskiego. Obydwie bywają krytyczne, ale nie widać w nich belferskiego tonu. Autorzy po prostu albo omawiają to, czego im w Kapitalizmie brakuje, albo pokazują, dlaczego nie podzielają któregoś z moich postulatów, czy nie zgadzają się z którą́s z tez. Urbański na przykład pisze, że w Kapitalizmie w ogóle nie ma walki klas, a również z tej perspektywy można ujmować przejęte przeze mnie od Harveya pojęcie spatial fix. U Sowy symptomatyczne jest natomiast to, że zamiast o różnicy zdań czy odmiennych interpretacjach pisze on o „błędach” (słowo to często powraca w jego recenzji).

Jednym z błędów, które rzekomo popełniam, jest niewłaściwe zreferowanie teorii przestrzeni Neila Smitha. Rozdział 17 Kapitalizmu poświęcony jest odejściu od reżimu przestrzeni absolutnej na rzecz reżimu przestrzeni relacyjnej, które w moim przekonaniu wyznacza moment narodzin kapitalizmu w waskim tego słowa znaczeniu. Sowa zauważa:

\footnotetext{
Tymczasem w klasycznej książce Smitha Uneven Development. Nature, Capital, and the Production of Space mowa jest o przestrzeni absolutnej oraz względnej (są one definiowane poprzez odniesienie do Newtona i Einsteina, więc nie mamy specjalnie dużego wyboru, jak przekładać owe angielskie terminy na język polski). W przypisie Smith wspomina, że „Harvey w Social Justice wprowadza trzecie pojęcie - przestrzeń relacyjną - jednak rozróżnienie na przestrzeń względną i relacyjną nie jest wystarczająco wyjaśnione" (Smith 2008, 277). Pobłocki wydaje się też nadawać terminowi przestrzeni relacyjnej nieco inne znaczenie, niż ma przestrzeń względna u Smitha, być może więc chodzi raczej o pojęcie Harveyowskie.
}

Żałuję, że Sowa nie sięgnął do drugiej książki Smitha (pt. American Empire: Roosevelt's Geographer and the Prelude to Globalization), która równie często (a nawet częściej) cytuję w rozdziale 17. Faktycznie, Smith przejął cała dyskusję o różnych rodzajach przestrzeni od Harveya, a ten od Henriego Lefebvre’a. O ile Harvey pisał zarówno w 1973 roku, jaki i dziś (a dokładniej w Spaces of Cosmopolitanism) pisze o trzech rodzajach przestrzeni, Smith zawsze wspomniał o dwóch. O ile w Uneven Development ten drugi rodzaj przestrzeni poza przestrzenia absolutna Smith nazywał względna, o tyle później, mając dokładnie to samo na myśli, nazywał ja przestrzenia relacyjna. Harvey, w przeciwieństwie do Smitha, nigdy nie łączył kwestii występowania trzech rodzajów przestrzeni z kwestia genezy kapitalizmu. Dlatego bardzo wyraźnie zaznaczam, że moja analiza w rozdziale 17 idzie ścieżką wyznaczona przez Smitha, a nie przez Harveya (choć wspominam też, że jest komplementarna wobec tego, co ten ostatni nazywał „urbanizacja kapitału”). Nie jest to więc żaden błąd, ani tym bardziej błędna interpretacja, ale po prostu decyzja autora dotycząca tego, jakim aparatem pojęciowym chce się posługiwać. Pozostaje pytanie, dlaczego w Kapitaliz̨mie nie została omówiona - przy uwzględnieniu stanowisk 
przywoływanych autorów - dyskusja dotycząca tego, czy istnieją dwa, czy trzy rodzaje przestrzeni. Powód, dla którego postanowiłem oszczędzić czytelnikom (zarówno akademickim, jak i laickim) tych dywagacji, jest prosty: nie wnoszą one nic do argumentacji, którą chcę przeprowadzić. Moim celem nie jest popisywanie się znajomością teorii Smitha, Harveya i Lefebvre'a, ale wybranie z nich tego, co jest mi potrzebne do zrealizowania założeń książki, czyli do odpowiedzi na pytanie, czym jest i skąd wziął się kapitalizm.

Dochodzimy tutaj do kwestii zasadniczej, czyli do zagadnienia polityczności Kapitalizmu. Sowa zarzuca mi, że nadużywam słowa „my”, że jest ono niedoprecyzowane i że w zasadzie autorem tej książki spokojnie mógłby być Andrzej Zybertowicz. I dalej: „czytając Kapitalizm, zastanawiałem się kilka razy, na kogo głosowałby Pobłocki w polskich wyborach i właściwie dopiero obszerne oraz afirmatywne odniesienie do anarchizującej antropologii Pierre'a Clastres'a przekonało mnie, że na pewno nie byłby to PiS”. Tak się składa, że Janek doskonale wie, na kogo głosuję, więc uwagę tę postrzegam jako chłopackie (i moim zdaniem niepotrzebne) kopanie się po kostkach. Ale myślę też, że sprawa jest poważniejsza. Jak wspomniałem, Sowa zżyma się, że już w pierwszym zdaniu książki używam słowa „my”, nie doprecyzowując, kogo mam na myśli. „Czy chodzi o antropologów, do których Pobłocki się zalicza? Czy o pracowników akademickich? Czy o Polaków i Polki? Czy może o humanistów i humanistki? Czy może, szerzej, o zainteresowanych światem społecznym badaczy i badaczki z obszaru nauk humanistycznych i społecznych? Czy też o ludzi, którym nie podoba się współczesny świat i którzy chca go zmienić? Czy może o całą ludzkość? Nie wiadomo”. Sowa wolałby, abym jasno i wyraźnie zadeklarował, do którego współczesnego plemienia należę. Tymczasem tutaj wcale nie chodzi o mnie, bo nie napisałem tej książki dla siebie, ale o (potencjalnych) czytelników. Używanie słowa „my” również jest zabiegiem performatywnym. I najbardziej politycznym gestem obecnym w tej książce.

Nie tylko Sowa zauważył, że ostatnie słowo Kapitaliẓmu to „zmiana”. To też nie przypadek. Wiele osób narzekało, że w książce brakuje wskazań dotyczacych tego, „co robić”. Kapitalizm nie jest manifestem politycznym. Zresztą nie wierzę w książki-manifesty. Moje (skromne) doświadczenie polityczne nauczyło mnie jednej rzeczy: że polityki nie uprawia się przez pisanie książek. Praca intelektualna i praca polityczna to dwie zupełnie inne sprawy. Oczywiście czasami się one zazębiaja, ale częściej jest tak, że to teoretycy mogliby się więcej nauczyć od praktyków, a nie odwrotnie (Anty-Bęradnik przestrzenny, który napisałem w 2013 roku wraz z dwójką poznańskich społeczników, pokazywał, jak stworzyć teorię na bazie wniosków wyciagniętych z działalności ruchów miejskich). Współcześnie w przestrzeni publicznej mamy bardzo wiele osób, które nie szczędzą dobrych rad, ale pozostają na wygodnych pozycjach komentatorów. Niektórzy intelektualiści uważają wręcz, że receptą na sukces polityczny jest przekucie na praktykę teorii, które oni wykładają w akademickich książkach. Uważam, że za takimi postawami kryje się bardzo duża arogancja i niezrozumienie 
tego, na czym faktycznie polega uprawianie polityki. W teorii nie ma różnicy między teorią a praktyka; w praktyce jednak różnica ta jest kolosalna.

Dzięki działalności publicznej nauczyłem się również tego, że polityka to budowanie wspólnoty, opartej na wykalibrowanej i świadomej inkluzji. Uważam, że właśnie tworzenie nowego „my” (choć oczywiście opartego o rozpoznane interesy czy też istniejące już więzi lub instytucje) leży u podstaw każdego udanego projektu politycznego. Tak przecież wygląda poszerzanie wpływu i poparcia dla obecnej partii rządzącej. Tak też postrzegałem kongres założycielski Partii Razem - jako moment przetasowania i otwarcia, który konstytuował nową wspólnotę, podmiot polityczny, zwany tam potocznie „optyczną większością”2. Odwoływanie się do istniejących podziałów jest w moim przekonaniu niewystarczające. Sukces polityczny zależy od umiejętności budowania nowych wspólnot, często powstających na przecięciu dawnych linii podziału. Dlatego właśnie używam w książce słowa „my”. Moim celem politycznym nie było napisanie manifestu dla którejś z partii, sporządzenie listy polityk, które należy wdrożyć, czy też przedstawienie zestawu dobrych rad dla tej czy innej osoby publicznej. Polityczność Kapitaližmu polega na tym, że sama książka jest inkluzywna i demokratyczna. Obniżenie progu wejścia do dyskusji o kapitalizmie i ekonomii dokonuje się więc nie tylko za pomoca przystępnego języka oraz struktury wywodu, która pozwala na przyswojenie dużej ilości tekstu akademickiego bez zbytniego dyskomfortu. Inkluzyjność polega też na tym, że każdy, dosłownie każdy, może się w tym „my” początkowo odnaleźć. Dotyczy to również tych osób, które głosowały w poprzednich wyborach na PiS.

Celowo używam słów „każdy” oraz „początkowo”, bo powyższe rozpoznania nie oznaczają oczywiście, że w tej książce każdy się ostatecznie odnajdzie. Na pewno wiele osób w którymś momencie przestało ją czytać. Jest ona, powtórzę to, precyzyjnie „wykuratorowana” podróżą teoretyczna. Jeśli jednak, jako autor, będę w stanie do ostatniej strony utrzymać przy sobie takiego czytelnika, który należy dziś do zupełnie innego plemienia politycznego niż ja, to w moim przekonaniu osiągnę w ten sposób sukces. Bowiem jeśli czytelnik ten odbędzie ze mną ową podróż po kapitalizmie i poświęci własny czas na to, aby przeczytać ponad sześćset stron tekstu, to mogę założyć, że zacznie, choćby w minimalnym stopniu, patrzeć na świat tak, jak ja bym tego chciał. Najłatwiej jest - szczególnie używając środowiskowego żargonu przekonywać przekonanych. O wiele trudniej jest przeciąnnąć na swoją stronę tych, którzy sami zaliczają się do innego plemienia i mówią innym językiem niż my. Dlatego tak duży opór z mojej strony wywołuje twierdzenie, że wszystko już było u Marksa. „Posługując się kategoriami Marksowskiej i marksistowskiej analizy, da się więc powiedzieć to wszystko, co powiedzieć chce Pobłocki, a nawet więcej”, twierdzi Sowa. Co z tego? Tego rodzaju gesty są, powtórzę to, niezwykle konserwatywne, w tym sensie, że cementuja (intelektualny oraz

\footnotetext{
${ }^{2}$ http://publica.pl/teksty/optyczna-wiekszosc-51653.html
} 
polityczny) status quo. Można oczywiście uporczywie przekonywać odbiorców, że egzegeza dzieł Marksa wystarczy do zrozumienia otaczającego nas świata, a ci, którzy tego nie widzą, po prostu błądza. Dla mnie jednak o wiele bardziej produktywnym (politycznie) gestem jest próba opowiedzenia świata na nowo, nowym językiem, który oczywiście wyrasta z wrażliwości teoretycznej takich autorów jak Marks, ale jest, mimo wszystko, językiem autonomicznym.

Podsumowując, myślę, że najważniejsza w chwili obecnej jest dla mnie dyskusja o tym, jak pisać książki naukowe. Rozróżnienie na książki akademickie, które są pisane hermetycznym językiem, i książki popularnonaukowe jest moim zdaniem szkodliwe i niedemokratyczne. Zamiast najpierw pisać książki „dla kolegów”, a następnie tłumaczyć je z naukowego na polski, postuluje pisanie książek polifonicznych - to znaczy takich, które sa jednocześnie akademickie oraz przystępne. Naukowcy udają, że pisanie książek naukowych nie jest pisaniem. Ale przecież wiemy (historycy dowiedzieli się tego chociażby od Haydena White'a), że to nieprawda. Dominująca wciąż struktura książki akademickiej jest w moim przekonaniu bardzo przedawniona. Budowa klasycznych książek naukowych (od przeglądu literatury, poprzez wyartykułowanie problemu badawczego, omówienie metod, przedstawienie wyników badań, po dyskusję o ich konsekwencjach) wynika z przekonania, iż celem działalności naukowej jest wypełnienie jakiejś luki w wiedzy. Tyle że dzisiaj nie tak postrzega się cele nauki-empirycznych luk w wiedzy jest tak dużo, że nigdy nie uda się ich wszystkich wypełnić. Jeśli celem współczesnej humanistyki ma być tworzenie pojęć (a badania empiryczne mają coś wnieść do debat teoretycznych), to oznacza to, że powinniśmy również inaczej pisać książki akademickie.

Myślę, że w tej kwestii Sowa i ja mamy ze sobą dużo wspólnego i różnimy się od takich autorów jak Kamil Śmiechowski, który ze względu na przystępność języka oraz „chaotyczność” struktury wręcz odmawia Kapitaližmowi naukowości. Ale ważne jest jeszcze coś innego: nauka nie powinna być oderwana od społeczeństwa, gdyż przez to staje się słabą nauką. W całej dyskusji o „nauce zaangażowanej” (czy to socjologii, czy antropologii etc.) nie chodzi o to, żeby akademicy użyczali swojego autorytetu aktywistom, ale o fakt, że wejście w relację z tym, co w antropologii nazywamy terenem, jest w stanie wygenerować nową (i lepsza) wiedzę. Przykład miasta jest dobry - dziś akademicy badaja ruchy miejskie. Ale przecież to pojęcie zostało stworzone przez nas, społeczników w Poznaniu, aby nazwać coś, co działo się w miastach, a na co nikt jeszcze wtedy nie miał dobrego określenia. To właśnie wyjście w „teren” oraz przekroczenie tradycyjnych barier między badaczem a badanym (czyli „badanie przez działanie”), pozwoliło powiedzieć coś nowego. Dlatego Anty-Bęradnik jest książka, która pokazuje, jak przekuć wiedzęzdobytą przez aktywistów (m.in. poprzez udział w postępowaniach administracyjnych czy sądowych) na teorię dotyczącą tego, jak „wytwarzana” jest polska przestrzeń. Ta książka, podobnie jak Kapitaliżm, proponuje pewną siatkę pojęć. Również i ta publikacja miała na celu zbudowanie pewnej wspólnoty - wiedza tam przekazana mogła mieć dla akademików znaczenie teoretyczne, a dla laików znacznie 
praktyczne (można było uczyć się dzięki omówionym tam przykładom kampanii społecznych oraz korzystać z zawartej tam wiedzy prawnej). W pewnym sensie więc Kapitaliæm jest bardzo podobny do Anty-Bezradnika - choć obydwie książki dotyczą zupełnie innych tematów i maja zupełnie inna strukturę, to cel, jaki im przyświecał, był identyczny. Obydwie wyrastały ze świadomości, że medium is the message. Obydwie opierały się na zrozumieniu, że performatywność książek akademickich nie jest związana jedynie z „wypełnianiem luk” w wiedzy.

Oczywiście Kapitaliz̨m nie jest pierwszą książką naukowa, która pożycza narzędzia od literatury, aby powiedzieć coś bardziej dobitnie lub wygenerować jakieś doświadczenie intelektualne. Jednym z historyków, którzy we wspaniały sposób eksperymentuja ze struktura książek, jest Karl Schlögel. Jego tom o Moskwie w 1937 roku jest wspaniała, otwarcie bułhakowowską podróżą po mieście, a książka In Space We Read Time (którą odkryłem dopiero niedawno) jest bardzo podobną (w swej „chaotyczności”) do Kapitalizmu próbą spojrzenia na historię przez pryzmat przestrzeni, a nie czasu. W socjologii mamy Matthew Desmonda, którego Evicted na pewno przejdzie do historii jako jedna z najwspanialszych etnografii, a w studiach miejskich warto wspomnieć chociażby o Mike'u Davisie i jego City of Quartz: W każdym z tych przykładów autorzy przekraczali bariery tego, co konwencjonalnie rozumie się przez akademicką monografię, gdyż było to merytorycznie niezbędne. Schlögel potrzebował tego, aby pokazać doświadczenie terroru 1937 roku w całej jego złożoności, Davies, aby uchwycić „spójność przestrzenną” Los Angeles i pokazać, jak fragmenty miasta i historie jego mieszkańców splatają się w logiczną całość, a Desmond, aby za pomoca historii czarnoskórych kobiet zmagających się z eksmisjami zwrócić uwagę opinii publicznej na fakt, że obwinia się ofiary, zamiast im pomagać.

Jeśli spojrzymy na te trzy książki jak na dzieła literackie, to zrozumiemy fakt, że także literatura mogłaby się wiele nauczyć od nauki. Bowiem wbrew samozadowoleniu wielu pisarzy i pisarek literatura (na co zwraca uwage m.in. Amitav Ghosh w The Great Derangement) nie jest w stanie znaleźć odpowiedniego języka do tego, aby opisać współczesny świat. Ghosh ma tu na myśli głównie zmiany klimatyczne, ale problem oderwania się współczesnej literatury od rzeczywistości (widoczny chociażby w dość symptomatycznym skupieniu się pisarzy, dotyczy to bowiem zwłaszcza płci męskiej, na samych sobie) jest tak samo poważny, jak kwestia zamknięcia się akademii w wieży z kości słoniowej. To właśnie wrażliwość teoretyczna umiejętność dostrzegania nowych światów tam, gdzie inni ich nie widzą - stoi u podstaw myślenia akademickiego i to ona stanowi największy atut współczesnej akademii. Byłoby wspaniale, gdyby wrażliwość ta udzieliła się również literatom. Bo to, że naukowcy korzystaja z narzędzi literackich, nie jest dziś ani niczym nowym, ani szczególnie zaskakującym. 


\section{Wykaz literatury}

Gellner, Ernest. 1989. Plough, Sword and Book. The Structure of Human History. Chicago: University of Chicago Press.

Pobłocki, Kacper. 2017. Kapitalizm. Historia krótkiego trwania. Warszawa: Fundacja Bęc Zmiana.

\section{Recenzje Kapitalizmu. Historii krótkiego trwania}

Czarnacka, Agata. 2017. „Konglomerat »czasopoglądów«”. La Vie Magazine 14 października Dunin, Kinga. 2018. „Eks-centryczny kapitalizm”. Krytyka Polityczna 11 stycznia

Grela, Szymon. 2017. „Ekonomia bez prostych rozwiązań”. Res Publica Nowa 229: 107-108 Klewenhagen, Adam. 2018. „Kapitalizm to metafora”. Maky Format 2

Kuligowski, Piotr. 2017. „Podróż po kapitalizmie”. Czas Kultury 4: 143-147.

Majewski, Robert. 2017. „Czas to pieniądz, czyli życie i śmierć kapitalizmu”. Wyborcza.pl (Płock) 14 września

Moll, Łukasz. 2017. „Dwa trwania kapitalizmu”. Praktyka Teoretyczna 4 października

Sowa, Jan. 2017. „Dziewiętnaście Long Reads o »tysiącu lat niewolnictwa«”. Praktyka Teoretycz̧na 16 października

Śmiechowski, Kamil. 2017. „Kapitalizm. Historia krótkiego trwania - recenzja”. Histmag.org 6 grudnia

Urbański, Jarosław. 2018. „Siła pieniądza czy siła pracy?”. Le Monde Diplomatique (edycja polska) luty: $36-40$.

Woś, Rafał. 2017. „O Mieszku kapitaliście”. Džiennik Gazeta Prawna 18 sierpnia.

Zdziebłowski, Szymon. 2017. „Intrygująca wycieczka po kapitalizmie”. Nauka w Polsce 8 września 
Kacper Pobłocki - jest antropologiem społecznym. Studiował w United World College of the Altantic (Wielka Brytania), University College Utrecht (Holandia) oraz Central European University (Wegry). Jego praca doktorska pt. The Cunning of Class - Urbanization of Inequality in Post-war Poland (2010) została wyróżniona nagrodą Prezesa Rady Ministrów. Autor tekstów z zakresu studiów miejskich, antropologii porównawczej i ekonomicznej oraz historii społecznej. W 2009 roku stypendysta kierowanego przez Davida Harveya ośrodka The Center for Place, Culture and Politics przy The City University of New York. Współautor książki Antybezradnik przestrzenny - prawo do miasta $w$ driałaniu (2013, nagroda im. Jerzego Regulskiego) oraz współredaktor książki Architektura nięrównoważona (2016). Pracuje w Instytucie Etnologii i Antropologii Kulturowej Uniwersytetu im. Adama Mickiewicza w Poznaniu oraz w Centrum Europejskich Studiów Lokalnych i Regionalnych Uniwersytetu Warszawskiego.

\section{DANE ADRESOWE:}

Instytut Etnologii i Antropologii Kulturowej UAM

Collegium Historicum

ul. Umultowska $89 \mathrm{D}$

61-614 Poznań

Centrum Europejskich Studiów Regionalnych i Lokalnych

Uniwersytet Warszawski

ul. Krakowskie Przedmieście 30

00-927 Warszawa

EMAIL: poblocki@amu.edu.pl

CYTOWANIE: Pobłocki, Kacper. 2017. Dwie podróże po kapitalizmie, czyli odpowiedź Janowi Sowie. Praktyka Teoretyczna 4(26): 387-410

DOI: $10.14746 /$ prt.2017.4.15

\section{AUTHOR: Kacper Pobłocki}

TITLE: Two Trips to Capitalism, or An Answer to Jan Sowa

ABSTRACT: This text is a reply to Jan Sowa's article Capitalism: A court durée History Nineteen Long Reads about "One Thousand Years of Slavery." The author addresses the arguments and objections formulated in the text, and presents his own opinion on the social role and the function of academic discourse. The main issues raised in the text are the relation of the author's project to the theory of Karl Polanyi (in particular his theory of the three fictitious commodities constituting the basis of capitalism), an interpretation of the theoretical 
meaning of the dispute about the notion of space in the analysis of capitalism, and the issue of the de-westernization of theory.

KEYWORDS: history of capitalism, Sowa, Occidentalism, Polanyi, dependence theory, theory of history, critical geography 